\title{
Effects of competition on the postfire recovery of 2 bunchgrass species
}

\author{
GUILLERMO E. DEFOSSÉ AND RONALD ROBBERECHT
}

\begin{abstract}
Authors are Research Scientist, Centro Nacional Patagónico (CONICET), (9120) Puerto Madryn, Chubut, Argentina; and Associate Professor, Department of Range Resources, University of Idaho, Moscow, Ida. 83844, USA. At the time of the research, the senior author was graduate student, Range Resources Department, University of Idaho, Moscow, Ida.
\end{abstract}

\begin{abstract}
The effect of competition on the postfire recovery of Festuca idahoensis Elmer and Agropyron spicatum (Pursh) Scrib \& Smith, was examined under natural conditions. Thirty plants of each species were exposed to fire applied with a portable instrument system that allowed precise control of fire temperature and duration, so that all plants received statistically similar fire severity levels inside the meristematic crown region. Treated plants were subjected to different levels of competition by periodically removing all or part of the aerial biomass around a monitored bunchgrass plant. Soil water potential, soil temperatures, and plant productivity were determined at monthly intervals during the growing season for the different competition treatments. No significant mortality due to fire was observed for plants of either species. Although Festuca did show meristematic tissue damage after fire, regrowth that occurred within 15 days after fire was more rapid than for Agropyron. Only Agropyron plants without competition reached prefire productivity levels. Soil water potential was significantly more negative in plots with competition. Temperatures in the upper 10-cm of the soil profile were significantly higher in plots without competition. Competition reduced root production and also restricted aboveground productivity by approximately $70 \%$ for Agropyron and $115 \%$ for Festuca. The capacity of these species to survive fire appears to be related more to the micro-environmental conditions created following fire and to their capacity to compete for available soil water, than to the direct effects of fire on plant tissues.
\end{abstract}

Key Words: fire, competition, Agropyron spicatum, $P_{\text {seudoroegneria }}$ spicata, Festuca idahoensis, soil water potential, soil temperature.

Fire is a major factor affecting plant community development (Daubenmire 1968, Old 1969, Vogl 1974, Noste 1985, Knapp 1986). In water-limited environments, plant productivity in the first growing season after fire is generally reduced relative to prefire levels (Blaisdell 1953, Conrad and Poulton 1966, Redmann 1978). The regrowth of perennial grasses after fire is a function

Research was funded in part by a grant from the Seed Grant Program, University of Idaho Research Council and USDA Forest Service Grant 22-C-4 INT-170. Authors wish to thank Dr. S. C. Bunting for his advise on the initial design of the flame ring. Additional support was provided by the Forest, Wildlife and Range Experiment Station.

(Contribution no. 793).

Manuscript accepted 21 May 1995. of the direct effects of fire on plant tissues, exposure to a more stressful post-fire environment, and plant competition with newly established herbaceous and annual grass species during the early stages of community development after fire (Daubenmire 1968). The relative importance of these factors is unclear, and comparison among different studies is made difficult because quantitative measures of fire exposure and environmental parameters for individual plants are generally lacking.

The disturbance of a plant community by fire generally results in a more xeric environment for plant establishment or regrowth. The darkened bare soil areas resulting from the removal of vegetation by fire increases the absorption of incident solar radiation at the soil surface, which subsequently affects the thermal energy balance of the soil (Margaris 1981, Roy and ArianoutsouFaraggitaki 1985). Plants that establish or regrow shortly after the fire are, therefore, exposed to higher soil temperatures and increased evapotranspiration rates relative to the undisturbed community (Naveh 1975, Arianoutsou and Margaris 1981, Raison et al. 1986, Sumrall et al. 1991).

Competition among plants for soil water in the more xeric postfire environment may be a significant influence on the rate of individual plant regeneration, and ultimately on species composition and community structure. Species that are sensitive to fire injury, but have a high competitive capacity relative to other species in the early stages of community development following fire, may dominate species that are initially less sensitive to fire, but are less effective competitors. Since the influence of competition among plants for soil water is a significant influence for plant establishment, growth and survival in water-limited environments (e.g., Harris 1967, Nobel 1981, Fonteyn and Mahall 1981, Robberecht et al. 1983), such interaction among plants in the following growing season could be highly significant (Redmann 1978).

The present study, therefore, addressed the effects of interspecific competition on the postfire regrowth of Festuca idahoensis Elmer and Agropyron spicatum (Pursh) Scrib \& Smith'. The degree of root system overlap among species, root and shoot productivity, and soil water availability in the postfire environment were primary considerations for the study of interspecific competition. The objectives of this investigation were therefore to determine: (1) the direct effects of a similar fire exposure on the sur-

$\longdiv { \text { Pseudoroegneria spicata (Pursh) A. Löve subsp. spicata (Barkworth and Dewey } }$ 1985). 
vival of Festuca idahoensis and Agropyron spicatum under natural conditions, (2) the influence of interspecific competition on the regeneration of these species during the early stages of community development following fire, and (3) how the different levels of interspecific competition affect the productivity of each species.

\section{Methods}

\section{Study Site}

This research was conducted at the University of Idaho Experimental Forest, $52 \mathrm{~km}$ northeast of Moscow, Ida., on a south-facing slope of the East Creek Unit (Basalt Hill, $46^{\circ} 52^{\prime} \mathrm{N}$, $\left.116^{\circ} 47^{\circ} \mathrm{W}\right)$. The vegetation at the study site was composed of widely spaced Pinus ponderosa Dougl. trees with an understory composed of the bunchgrasses, Festuca idahoensis, Agropyron spicatum, and several herbaceous species. The vegetation can be classified as a Pseudotsuga menziesii/Physocarpus malvaceus habitat type (Daubenmire and Daubenmire 1968). The Carlington silt loam soil series of shallow and well drained soils characterize the area (Zimmerman 1979, Barker 1981). Winter precipitation occurs as snow, and moist spring and fall periods are interrupted by a mid-summer drought. The long-term precipitation and temperature means at the field site were similar to that for the Potlatch climatological station, approximately $10 \mathrm{~km}$ from the study site (Fig. 1). The mid-summer dry period during this study, however, was more severe than the average, since no precipitation occurred between late May and early September.

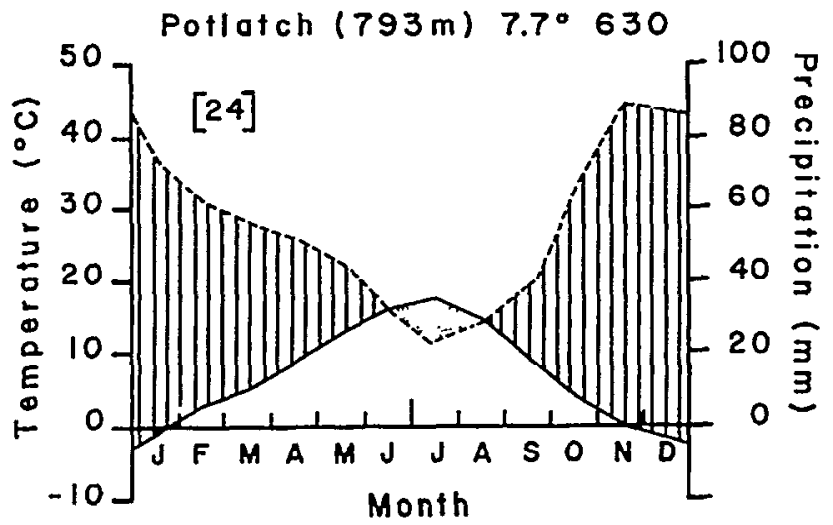

Fig. 1. Climate diagram in the format of Walter and Lieth (1960) for Potlatch, Ida. Mean monthly precipitation (broken line) and temperature (solid line) for 24-year period indicate mesic spring and fall periods interrupted by summer drought (stippling). Winter precipitation occurs as snow.

\section{Fire Exposure}

For each species, 30 plants of similar phenology and size, determined by basal area, height, and root biomass measurements, were selected in the study area. After selection, all Agropyron and Festuca plants were exposed to fire in early spring, before the initiation of significant growth had occurred. The fire was applied with a portable flame ring placed around individual bunchgrasses. This instrument, described in Robberecht and Defossé (1995), had 6 propane gas jets on a hexagonal aluminum ring adjustable to various heights. The jet arrangement and the regulated propane gas supply approximated the flame geometry of a grass fire. Thermocouples were placed at $10 \mathrm{~cm}$ above the soil surface in the canopy, inside the meristematic crown region, and at soil depths of 2,5 , and $10-\mathrm{cm}$ beneath each plant. The high temperatures expected in the plant canopy were measured with high-temperature range shielded thermocouples (ANSI type $\mathrm{K}, 0.5 \mathrm{~mm}$ diameter). Mean temperature inside the crown region was measured with three-junctioned thermocouples wired in parallel (ANSI type T, $0.5 \mathrm{~mm}$ diameter). Singlejunctioned thermocouples of this same type were used for measurement of temperatures in the soil beneath each plant. These thermocouples were connected to a data acquisition system (Campbell Scientific model CR 21X datalogger) for continuous (every 10 seconds) temperature measurement during the 10-min fire and postfire cooling phases. This instrument allowed for precise control over the fire temperature and its duration for individual plants. The fire was terminated when temperatures inside the crown meristematic region reached approximately $4^{\circ} \mathrm{C}$, which occurred at about 40 seconds after fire ignition. The data of mean crown temperatures achieved during the $10-\mathrm{min}$ fire and postfire cooling phases were downloaded to a computer and the integral of the time/temperature curve determined for each plant. Analysis of variance was used to determine significant differences among these integrals for this one-factor experiment. These integrals were used as an index of fire exposure, or severity, for each plant.

\section{Competition Experiment}

Following fire exposure, all Agropyron and Festuca plants were assigned to treatment levels of (1) intact or control, (2) partial removal of competitors, and (3) full removal of competitors. Ten plants of each species were assigned to each treatment level in a completely random statistical design. The 2 different levels of competition were achieved by partial (half of the aboveground green biomass of potential competitors removed) to full (all aboveground biomass of potential competitors removed) removal of the neighboring potential competitors within a radius of $0.6 \mathrm{~m}$ of the plant selected for observation. This radius was based on preliminary studies of the limits of lateral root distribution determined from excavations of the root system of typical adult plants of both species grown in the area. Regrowth of competitor plants was removed every 15 days during the growing season.

\section{Postfire Plant Response Measurements}

Following fire exposure, measurements of soil water content, soil temperature, culm number, and height were made throughout the growing season on plots with and without competition. Aboveground biomass of individual plants was determined at the end of the growing season. Root biomass was estimated for each plant from soil cores taken with a $2.5 \mathrm{~cm}$-diameter soil sampler at the beginning and end of the growing season. These samples were separated according to horizontal distributions of 0 to 5,5 to 10 , and 10 to $25 \mathrm{~cm}$-soil depth. Soil cores were taken at an angle of $45^{\circ}$ approximately $10 \mathrm{~cm}$ from the crown of each Festuca plant and at the same angle $15 \mathrm{~cm}$ from the crown of each Agropyron plant. This allowed sampling of soil volume with the greatest root concentration for each bunchgrass species and minimized the potential root overlap with neighboring plants. Total root biomass per core sample and its horizontal distribution, was determined for each plant from root samples that were washed free of debris and oven dried to constant weight. Culm height and 
number were determined approximately every 3 weeks. Mean soil water content was determined gravimetrically for the 0 to 10 and 10 to $20 \mathrm{~cm}$ soil depth from 8 replications each performed on plots with full competition (or controls) and on plots without competition. Soil water potential was estimated from these data using the filter paper method given by Hamblin (1981). Soil temperature around plants was measured approximately monthly, using an infrared thermometer (Barnes Instatherm, model 14220-1) for surface temperatures and thermocouple sensors for the 5,10 , and $25-\mathrm{cm}$ soil depths.

\section{Data Analyses}

Analysis of variance and Fisher's L.S.D were used to determine significant differences in culm number and height, total biomass, root biomass, and basal area among competition treatments for both species. The Student's " $t$ " test was used to determine significant differences in soil water potential and soil temperatures between plots with full competition (controls) and plots without competition.

\section{Results}

\section{Fire Characteristics}

The fire treatment applied in this study was qualitatively similar to that described for natural (Conrad and Poulton 1966) and controlled (Robberecht and Defossé 1995) grass fires. The plant canopy and the litter within a $0.5 \mathrm{~m}$ radius of the treated plants were consumed by the fire, resulting in a blackened bare soil area surrounding each treated plant. The instrument system used in this study allowed complete documentation of the fire exposure for each plant. The fire consumed the canopy within 15 seconds of the ignition, at which time only flame temperatures at the height of the canopy werc mcasured. No substantial increases in

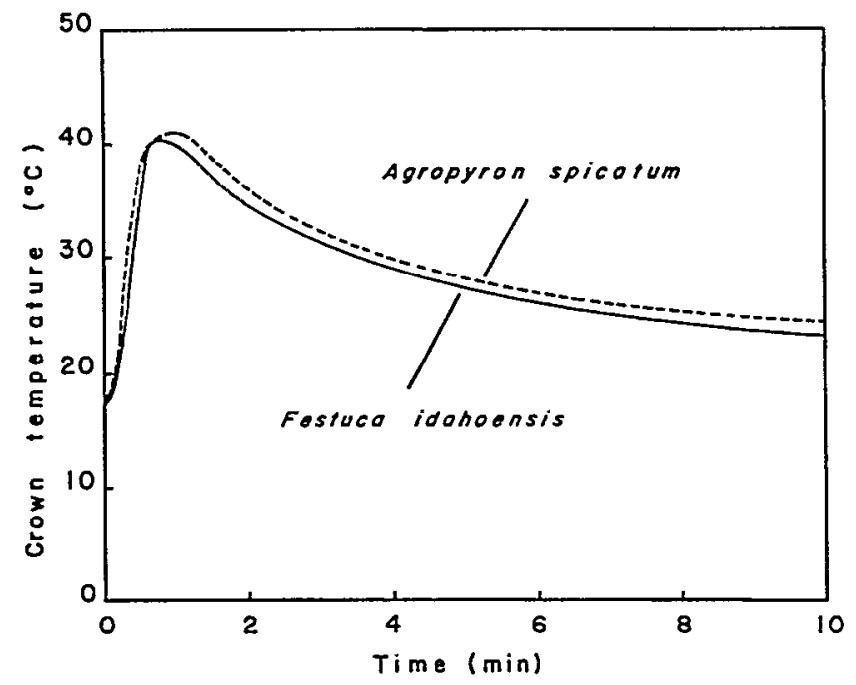

Fig. 2. Mean temperature curves for the meristematic crown region of Agropyron spicatum and Festuca idahoensis plants during the fire and postfire cooling periods. The standard error ranged between \pm 5 and $10 \%$ of the mean. The temperature/time integrals calculated from these data represent the fire severity treatment for each plant. Fire severity did not significantly $(p>0.01)$ differ among plants of each species. subsurface soil temperatures were observed in either the fire or postfire phases. Temperatures at the $2-\mathrm{cm}$ soil depth slowly increased in the first minutes after fire ignition, with a maximum increase of about $4^{\circ} \mathrm{C}$ near the end of the 10 minute treatment period. Temperatures at the $5-\mathrm{cm}$ soil depth increased only $1^{\circ} \mathrm{C}$ toward the end of the monitored period. No rise in temperature at the $10-\mathrm{cm}$ soil depth was detected during the monitored time. The temperatures experienced inside the meristematic crown region were similar for all Agropyron and Festuca plants (Fig. 2). Fire severity, the temperature/time integral, did not significantly differ ( $>0.01$ ) between species or among treatments within species.

\section{Soil Water Availability}

The removal of potential competitors significantly increased $(\mathrm{p}<0.01)$ the soil water available for the monitored plants of both species (Fig. 3). Soil water potential, estimated from measurements of soil water content (Hamblin 1981), was initially similar for all plots. During the growing season following fire, soil water potential decreased significantly more in the plots with a full degree of competition (control group) than in plots without competition. The effect of reduced plant competition on soil water potential was most pronounced in the 0 to $10-\mathrm{cm}$ soil depth during the mid-summer drought period (Fig. 3).

\section{Soil Temperature Regime}

Monitored plants of each species were exposed to higher soil surface temperatures after the fire and removal of neighboring

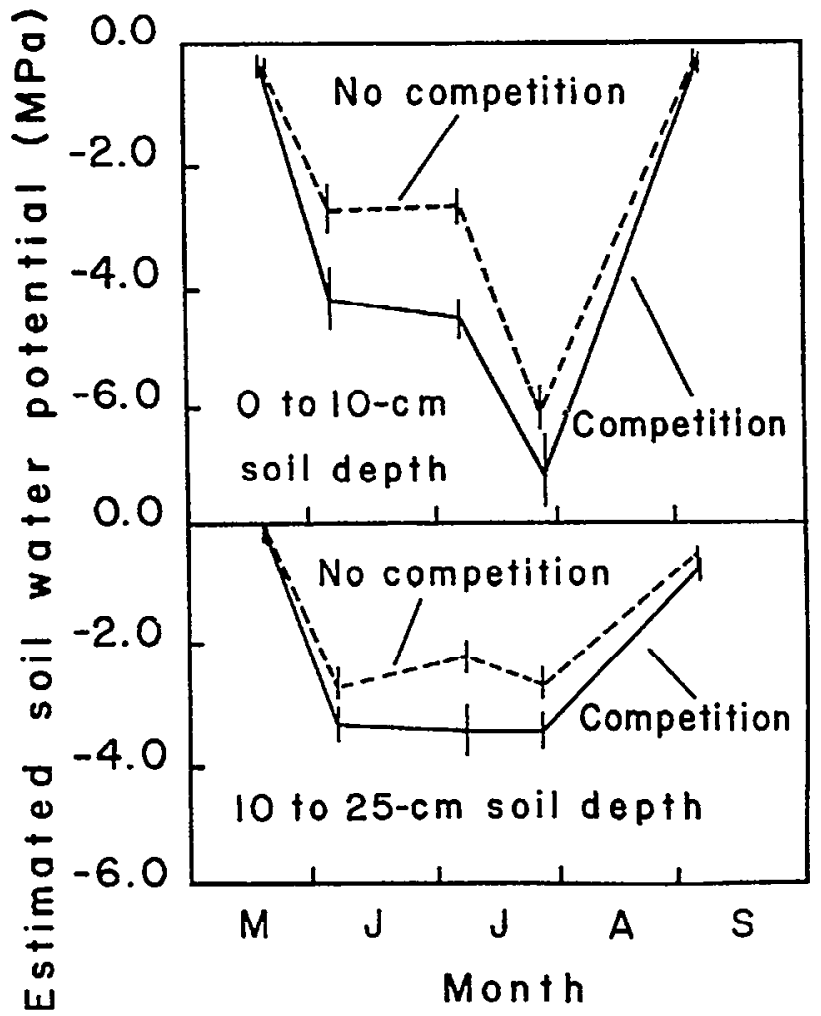

Fig. 3. Soil water potential estimated from soil water content (Hamblin 1981) for experimental plots with and without competition. Plots with plant competition exhibited significantly more negative $(p<0.01)$ soil water potentials than those without competition. Each point represents the mean of eight samples \pm 1 standard error (vertical line). 


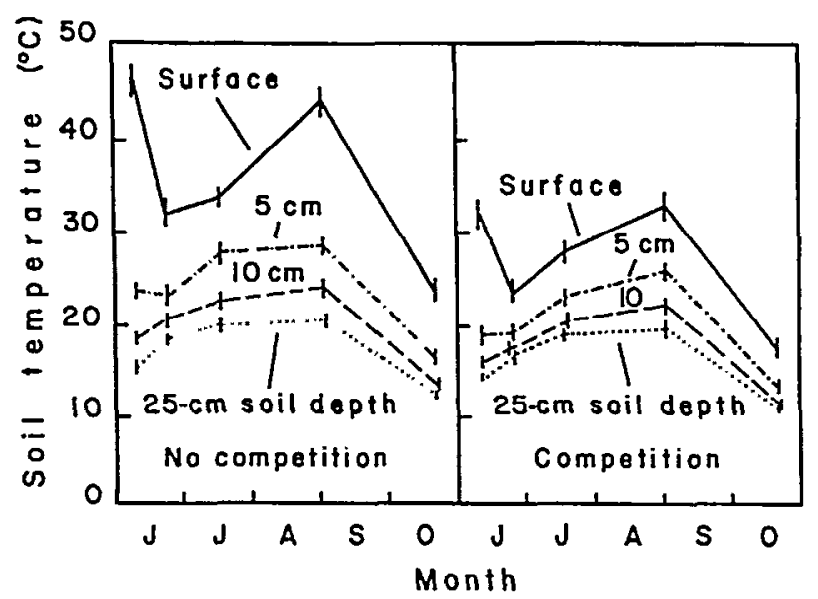

Fig. 4. Mid-day soil temperature profiles for plots with and without plant competition. Seasonal temperature variation was greatest at the soil surface and least at the $25-\mathrm{cm}$ soil depth. Each point represents the mean of six samples \pm 1 standard error (vertical line).

competitors. The darkened bare soil around these plants exhibited surface temperatures from 12 to $15^{\circ} \mathrm{C}$ higher than soil surface in plots from which competitors had not been removed (Fig. 4). Temperatures at the 5 and $10-\mathrm{cm}$ soil depths were also significantly increased $(\mathrm{p}<0.05)$ due to the removal of competitors. Soil temperatures at the $25-\mathrm{cm}$ soil depth did not statistically differ among plots with different levels of competition.

\section{Mortality and Leaf Damage}

No significant mortality resulted directly from the fire severity applied, as evidenced by the death of only one Agropyron plant during the experiment. Although some injury to meristematic tissue was indicated by damage to leaf blade tips observed during the initial postfire regrowth of Festuca plants, this effect was short-lived and did not inhibit plant regeneration. No such leaf damage was observed for Agropyron. Reproductive meristems may have been damaged, however, since flowering did not occur in either Festuca nor Agropyron by the end of the first growing season, while neighboring unburned bunchgrasses of the same species flowered.

\section{Aboveground Plant Response}

Festuca plants exposed to reduced competition from neighboring plants showed no significant increases in basal area during the growing season after fire. Basal area did significantly $(\mathrm{p}<0.01)$ increase for Agropyron in response to the complete removal of competitors. Regrowth of new leaf tissue was evident less than 2 weeks after the fire for Festuca versus 4 weeks for Agropyron plants. No significant differences in culm number were observed among treatments for either Festuca or Agropyron during this initial regrowth period.

The rate of regrowth for Festuca was greater than for Agropyron during spring and early summer when sufficient soil water was available (Fig. 5). The increase in plant height after the fire was affected by competition in a similar pattern asculm production (Fig. 6), and only Agropyron reached prefire culm heights. Culm height for Festuca approached a plateau in early summer, nearly 2 months before this occurred for Agropyron. For both species, however, the decline in the rate at which culms

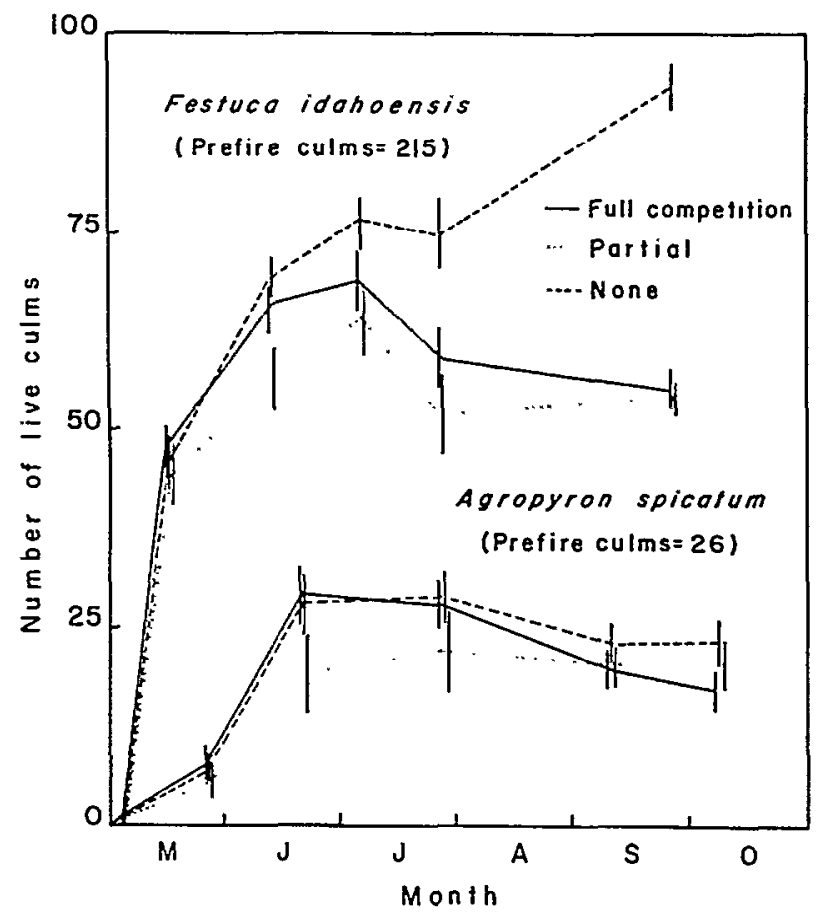

Fig. 5. Postfire production of new culms for plants exposed to three levels of competition. Reduced degree of competition from neighboring plants significantly increased culm production for both species. Each point represents the mean of 10 plants \pm 1 standard error (vertical line).

increased in height was delayed and end-season culm height was greater for plants that were not exposed to competition. Only culm production for Festuca plants not exposed to competition significantly increased in response to fall season precipitation. Plants of Festuca and Agropyron that were not exposed to competition exhibited significantly greater $(\mathrm{p}<0.01)$ biomass production than plants exposed to partial or full levels of competition from neighboring plants (Fig. 7).

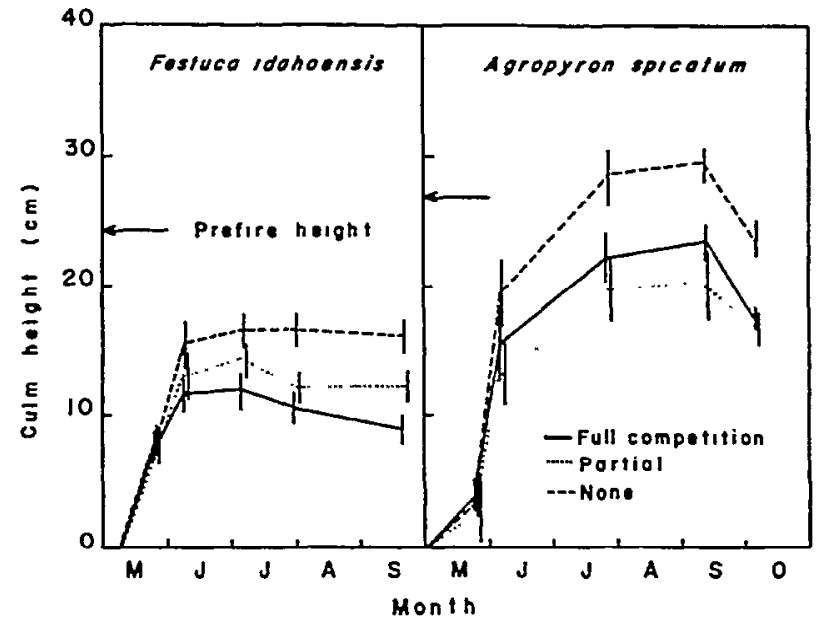

Fig. 6. The postfire increase in plant height for plants exposed to three levels of competition. Plants without competition from neighbors were significantly taller $(p<0.01)$ than plants exposed to partial or full levels of competition. Each point represents the mean of 10 plants +1 standard error. 
Culm production for both species was less for plants exposed to partial competition than to full competition. However, plants of Festuca exposed to the partial level of competition produced culms that were significantly taller than those culms produced in response to full competition (Fig. 6). In addition, whole plant response measured in end-season biomass did show that the partial removal of competitors resulted in an intermediate response. The lack of difference in aboveground biomass between the partial and full levels of competition for Agropyron may be explained by the deeper root system of this species, thereby reducing the overlap with neighboring species.

\section{Belowground Response}

The concentration of root biomass for the 2 bunchgrass species occurred at 2 different regions in the soil profile, with Festuca plants having a greater concentration in the upper $10 \mathrm{~cm}$ of the soil. In early spring, $40 \%$ of the root biomass of Festuca plants occurred in the first $\mathrm{cm}$ of the soil, $28 \%$ in the next $5 \mathrm{~cm}$, and $32 \%$ in the 10 to $25-\mathrm{cm}$ soil region. For Agropyron, by contrast, $21 \%$ of the root biomass occurred in the 5 -cm soil depth, $31 \%$ in the following $5-\mathrm{cm}$ depth, and $48 \%$ in the 10 to $25-\mathrm{cm}$ zone. At the end of the growing season, the pattern of root distribution was unchanged for Festuca, whereas that for Agropyron was more evenly distributed in the soil; $32 \%$ in the first $5 \mathrm{~cm}, 36 \%$ in the following $5 \mathrm{~cm}$ and $32 \%$ in the 10 to $25-\mathrm{cm}$ zone. The different levels of competition imposed did not alter the root distribution pattern in the soil. However, reduced competition from neighboring plants significantly increased total root biomass production in both species (Fig. 7).

\section{Discussion}

\section{Fire Severity}

The concept of fire severity involves the heat flux into the soil (MacArthur and Chenney 1966, Rowe 1983, Noste 1985, Ryan and Noste 1985). It has been influenced by the degree of organic material removed, the extent of soil heating, and the fire duration. Although the concept of fire severity is clear, it is difficult to measure. The biological and ecological response of plants to fire must be linked to quantitative measurements of fire behavior (Alexander 1982). In the present study, the change in temperature experienced inside the crown region was integrated over the monitored 10-min fire and postfire cooling period. This resulted in a quantifiable index of fire severity for individual plants that could be statistically analyzed for treatment differences. The knowledge that all plants received statistically similar fire exposure on their meristematic crown region was essential for separating the effects of the different levels of competition on the postfire regeneration of these bunchgrass species.

\section{Soil Temperatures}

Soil Temperature characteristics during the monitored fire and postfire cooling periods were similar to those found by Scotter (1970), Sumrall et al. (1991), and Robberecht and Defossé (1995) for grassland fires. No substantial increase in soil temperature was observed during the fire exposure, as evidenced by only a $4^{\circ}$ $\mathrm{C}$ increase at the $2-\mathrm{cm}$ soil depth. In grassland fires, temperatures decrease exponentially from the surface into the soil profile (Scotter 1970). In such communities soil temperatures tend to

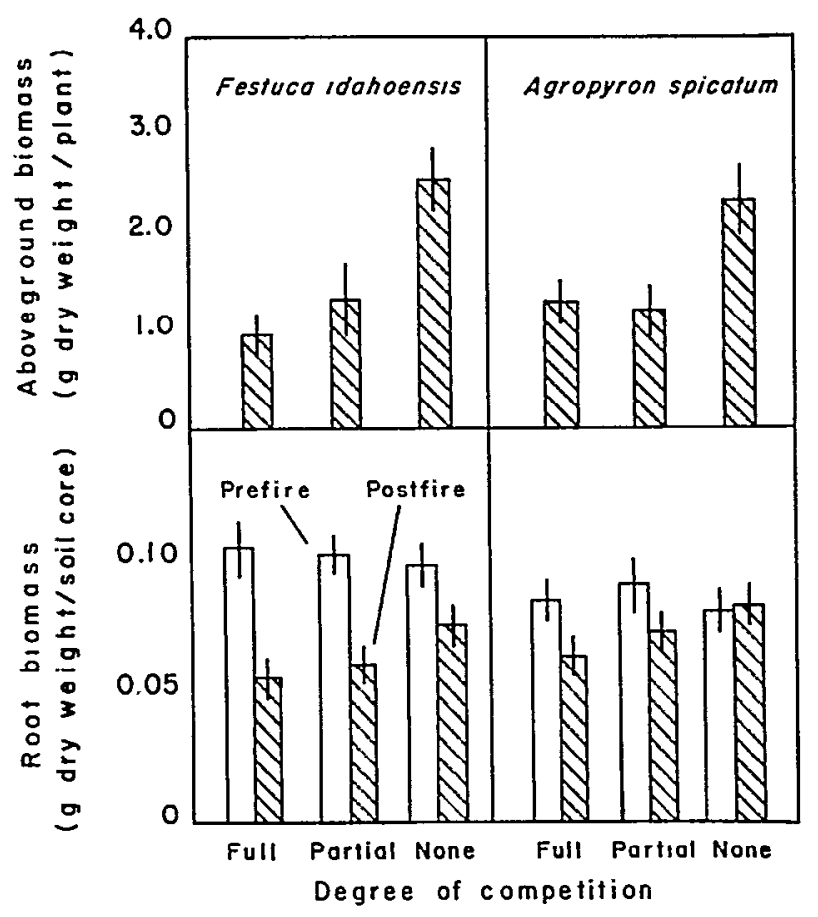

Fig. 7. (Top) Aboveground biomass determined at the end of the growing season. Plants exposed to competition produced significantly $(p<0.01)$ less biomass than plants without competition. (Bottom) Root biomass before and after fire for the 3 levels of plant competition. Plants without competition produced significantly $(p<0.01)$ more root biomass per soil core than plants with a full degree of competition. Prefire root biomass did not significantly differ among plants of each species.

return to prefire levels shortly after fire has occurred (Cook 1939, Masson 1948, Tothill and Shaw 1968, Scotter 1970).

The heat flux into the soil is, however, dependent on soil characteristics such as soil type and water content (Rosenberg et al. 1983). The results for Agropyron and Festuca, as well as those of other studies (e.g., Scotter 1970, Raison et al. 1986), indicate that the rise in soil temperature caused directly by fire is not of sufficient magnitude to influence the root system.

The postfire environmental changes associated with the occurrence of broad-scale grassland fires can significantly affect the soil temperature regime on a seasonal basis (Roy and Arianoutsou-Faraggitaki 1985, Sumrall et al. 1991). While soil temperature in all plots was initially a function of the increased absorption of solar radiation by the darkened soil surface after the fire, the periodic removal of potential competitors was the principal factor for increased insolation at the soil surface and the higher soil surface temperatures observed on those plots. Although increased soil temperature at greater depth could significantly affect root and rhizome growth during the postfire growing season (Scotter 1970), soil water availability during this period appears to be more significant for growth of perennial grasses (Redmann 1978).

\section{Fire and Competition Effects}

Fire in water-limited environments generally reduces the productivity of perennial grasses during the first postfire growing season (Blaisdell 1953, Daubenmire 1968, Wright 1974, Robberecht and Defossé 1995). Soil water availability during this 
period, particularly for species (e.g., Festuca idahoensis) with roots concentrated in the upper soil layers, may be critical for plant regeneration (Coupland and Johnson 1965, Redmann 1978). The decline of soil water availability in mid-summer restricted culm production more for Festuca than for Agropyron, so that only the latter achieved the prefire number of culms per plant. The rapid growth rate of Festuca only after periods of high water availability found in this study, and reports that this species has a low tolerance to drought stress (Tisdale and Hironaka 1981), suggest that the reduced culm production during the postfire growing season was more a function of soil water availability than direct fire damage to meristematic tissues. Agropyron is relatively more resistant to water stress (Caldwell et al. 1981) and has a root system that extends deeper into the soil, where the decline in soil water occurs later in the summer season. This may account for culm production to nearly prefire levels and continued growth in culm height throughout the summer drought period for Agropyron. The substantial reductions in productivity observed suggest that competition for soil water can be a significant factor for plant regeneration after fire. These results are in accordance with those reported by Melgoza et al. (1990) for a burned semiarid shrub-grass community. They found that after a fire, perennial plants growing in plots from which competitors had been removed, had more soil water available and produced higher biomass compared to plants growing in intact plots. Furthermore, in water-limited environments or in habitats that become more xeric after fire, the effect of competition for soil water may be more significant than the effects of fire alone (Melgoza et al. 1990). The influence of competition is particularly relevant to postfire community development since fire-sensitive species that are highly competitive during the early stages of community development after fire may become dominant over relatively more fire tolerant, but less competitive species.

\section{Literature Cited}

Alexander, M. E. 1982. Calculating and infcrpreting forest firc intensities. Can. J. Bot. 60:349-357.

Arianoutsou, M. and N. S. Margaris. 1981. Early Stages of regeneration after fire in a pyrogenic ecosystem (east Mediterranean) I: Regeneration by seed germination. Biol. Ecol. Medicine 8:119-128.

Barker, R. J. 1981. Soil survey of Latah County area, Idaho. USDA, SCS, Univ. Idaho Coll. Agr., Ida. Soil Conserv. Comm.

Barkworth, M. E., and D. R. Dewey. 1985. Genomically based genera in the perennial Triticale of North America: identification and membership. Amer. J. Bot. 72:767-776.

Blaisdell, J. P. 1953. Ecological effects of planned burning of sagebrushgrass range on the Upper Snake River Plains. USDA Tech. Bull. 1075.

Caldwell, M. M., J. H. Richards, D. A. Johnson, R. S. Nowak, and R. S. Dzurec. 1981. Coping with herbivory: Photosynthetic capacity and resource allocation in two semiarid Agropyron bunchgrasses. Oecologia 50:14-24.

Conrad, C. E. and C. E. Poulton. 1966. Effect of a wildfire on Idaho fescue and bluebunch wheatgrass. J. Range Manage. 19:138-141.

Cook, L. 1939. A contribution to our information on grass burning. South African J. Sci. 36:270-276.

Coupland, R. T. and R. E. Johnson. 1965. Rooting characteristics of native grassland species in Saskatchewan. J. Ecol. 53:475-507.

Daubenmire, R. 1968. Ecology of fire in grasslands. p. 209-267 In: J. B. Cragg (ed.) Advances in Ecological Research. Academic Press, New York-London.

Daubenmire, R. and R. B. Daubenmire. 1968. Forest vegetation of eastern Washington and northern Idaho. Washington Agr. Exp. Sta. Bull. 60. Pullman, Wash.
Fonteyn, P. J. and B. E. Mahall. 1981. An experimental analysis of structure in a desert plant community. J. Ecol. 69:883-896.

Hamblin, A. P. 1981. Filter paper method for routine measurement of field water potential. J. Hydrol. 53:355-360.

Harris, G. A. 1967. Some competitive relationships between Agropyron spicatum and Bromus tectorum. Ecol. Monogr. 37:89-111.

Knapp, A. K. 1986. Ecophysiology of Zigadenus nuttallii, a toxic spring ephemeral in warm season grassland: effect of defoliation and fire. Oecologia 71:69-74.

MacArthur, A. G. and N. P. Chenney. 1966. The characterization of fires in relation to ecological studies. Australian Forest Res. 2:36-45.

Margaris, N. S. 1981. Adaptative strategies in plants dominating Mediterranean type ecosystems. p. 355-384 In: F. di Castri (ed.). The ecosystems of the World II. Elsevier, Amsterdam.

Masson, H. 1948. La temperature du sol au cour d'un feu de brousse au Senegal. Agron. Tropical 3:174-179.

Melgoza, G., R. S. Nowak, and R. S. Tausch. 1990. Soil water exploitation after fire: competition between Bromus tectorum (cheatgrass) and two native species. Oecologia 83:7-13.

Naveh, Z. 1975. The evolutionary significance of fire in the Mediterranean region. Vegetatio 9:199-208.

Nobel, P. S. 1981. Spacing and transpiration of various sized clums of a desert grass, Hilaria rigida. J. Ecol. 69:735-742.

Noste, N. V. 1985. Influence of fire severity on response of evergreen ceanothus. USDA, For. Serv. Gen. Tech. Rep. INT-186.

Old, S. M. 1969. Microclimate, fire, and plant production in an Illinois prairie. Ecol. Monogr. 39:355-384.

Raison, R. J., P. V. Woods, B. F. Jakobsen, and G. A. V. Bary. 1986. Soil temperatures during and following low-intensity prescribed buming in a Eucalyptus pauciflora Forest. Australian J. Soil Res. 24:33-47.

Redmann, R. E. 1978. Plant and soil water potentials following fire in a northern mixed grassland. J. Range Manage. 31:443-445.

Robberecht, R. and G. E. Defossé. 1995. The relative sensitivity of two bunchgrass species to fire. Int. J. Wildland Fire. 5:127-134.

Robberecht, R., B. E. Mahall, and P. S. Nobel. 1983. Experimental removal of competitors. Effects on water relations and productivity of a desert bunchgrass Hilaria rigida. Oecologia 60:21-24.

Rosenberg, N. J., B. L. Blad, and S. B. Verma. 1983. Microclimate. Wiley, N.Y.

Rowe, J. S. 1983. Concepts of fire effects on plant individuals and species. p. 135-151 In: R. W. Wein and W. A. McLean (eds.). The role of Fire in Northern Circumpolar Ecosystems. Wiley, N.Y.

Roy, J. and M. Arianoutsou-Faraggitaki. 1985. Light quality as the environmental trigger for the germination of fire promoted species. Flora 177:345-349.

Ryan, K. C. and N. V. Noste. 1985. Evaluating prescribed fire. USDA For. Serv. Gen. Tech. Rep. INT-182.

Scotter, D. R. 1970. Soil Temperatures under grass fires. Australian J. Soil Res. 8:273-279.

Sumrall, L. B., B. A. Roundy, J. R. Cox, and V. K. Winkel. 1991. Influence of canopy removal by burning or clipping on emergence of Eragrostis lehmanniana seedlings. Int. J. Wildland Fire 1:35-40.

Tisdale, E. T. and M. Hironaka. 1981. The sagebrush-grass region. A review of the ecological literature. For. Wildl. Range Exp. Sta. Bull. 33, Univ. Idaho, Moscow, Ida.

Tothill, J. C. and N. H. Shaw. 1968. Temperatures under fires in bunch spear grass pastures of south-east Queensland. J. Australian Inst. Agr. Science 34:94-97.

VogI, R. J. 1974. Effects of fire on grasslands. p.139-182 In: T. T. Kozlowski and C. C. Ahlgren (eds). Fire and Ecosystems. Academic Press, N.Y.

Walter, H. and H. Lieth. 1960. Klimadiagramm-Weltatlas. Gustav Fischer, Jena.

Wright, H. A. 1974. Effect of fire on southern mixed prairie grasses. J. Range Manage. 27:417-419.

Zimmerman, G. H. 1979. Livestock grazing, fire, and their interactions within the Douglas fir/ninebark Habitat Type in northern Idaho. M. S. Thesis, Univ. Idaho, Moscow, Ida. 